\title{
Acute and Subchronic Toxicity Study of the Ethanol Extracts from Ficus deltoidea Leaves in Male Mice
}

\author{
Rudy Agung Nugroho ${ }^{1}$, Retno Aryani ${ }^{1 *}$, Hetty Manurung ${ }^{2}$, Rudianto Rudianto ${ }^{3}$, Widha Prahastika ${ }^{4}$, Amelia Juwita $^{1}$, Abdul \\ Khafizh Alfarisi ${ }^{1}$, Nur Ainun Oktavia Pusparini ${ }^{1}$, Agnesia Lalong ${ }^{1}$
}

${ }^{1}$ Laboratorium Fisiologi, Perkembangan dan Molekuler Hewan, Jurusan Biologi Fakultas Matematika dan IImu Pengetahuan Alam Universitas Mulawarman, Samarinda, Kalimantan Timur; ${ }^{2}$ Laboratorium Fisiologi Tumbuhan, Jurusan Biologi Fakultas Matematika dan IImu Pengetahuan Alam Universitas Mulawarman, Samarinda, Kalimantan Timur; ${ }^{3}$ Laboratorium Fisiologi, Perkembangan, dan Molekuler Hewan, Jurusan Biologi, Fakultas Matematika dan IImu Pengetahuan Alam, Universitas Mulawarman, Samarinda, Kalimantan Timur, Indoensia; ${ }^{4}$ Laboratorium Anatomi dan mikroteknik Hewan, Jurusan Biologi Fakultas Matematika dan IImu Pengetahuan Alam Universitas Mulawarman, Samarinda, Kalimantan Timur

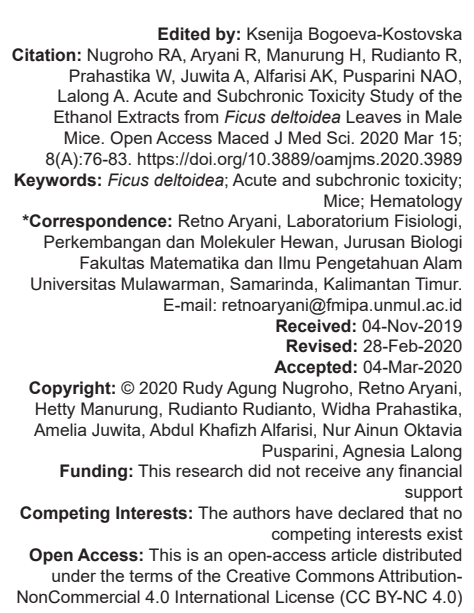

Introduction

In recent years, the use of medicinal plants has risen rapidly and is very popular. The World Health Organization has estimated that $80 \%$ of African and Asian residents use traditional medicines to maintain health and treatment of disease. Research on the use of traditional medicines, including herbal medicines, has been rapidly increased, both in developed and developing countries [1], [2], [3]. Indonesia, one of the developing countries, has a high biodiversity of plants that widely used as traditional medicine. One of the medicinal herbs that have been used by Indonesian ancestors is Tabat Barito (Ficus deltoidea Jack.) [4], [5].

F. deltoidea is a perennial cultivated plant whose height rarely exceeds $2 \mathrm{~m}$. In some countries, these plants are known by various names such as Mas Cotek in Malaysia, Barito Barat in Indonesia, Agoluran in the Philippines, and Kangkalibang in Africa [6]. In general, this plant lives as an epiphytic plant in the forest and its benefits have been studied in-depth lately. Every part of the plant is known to have benefits as a medicine. The fruit is chewed to relieve headaches and toothache; root powder and plant leaves have been applied outside medicine for wounds [7] and to eliminate rheumatism [8]. Conventionally, these plants are also consumed to help strengthen a woman's womb after giving birth [6], [9] and function as a libido booster for men and women [10].

By detonation of health therapy using plant material, the safety of medicinal plants has become a public health problem [11]. There is an increased awareness in the use of this herbal remedy [12] since most natural products or herbal medicines contain diverse phytoconstituents due to variations in growth patterns, geographical location, harvest time, and storage [13]. The correct identification of 
the compound composition in plants is essential to ensure consistent quality, safety, and efficacy [12]. Although F. deltoidea has some promising pharmacological potentials, it has not been widely tested for possible side effects. There are not many studies to evaluate the level of safety and toxicity. Further, it is necessary to do further testing in test animals to see whether there are any toxic effects to ensure the safety of their use. Herbal and synthetic raw materials must be ensured of their safety before they can be used as medicine. An important step in ensuring drug safety is conducting an appropriate toxicity test on animal models, where acute and subchronic toxicity tests are one of the main tests that must be carried out [14], [15], [16]. Therefore, the aim of this study was to evaluate the acute toxicity profile and repeated 28-day exposure (subchronic toxicity) from the ethanol extract of $F$. deltoidea leaves.

\section{Materials and Methods}

\section{Extract preparation}

F. deltoidea fresh leaves were collected, cleaned, dried, and mashed. The mashed leaves were macerated into ethanol $96 \%$ solvent for $2 \times 24$ $\mathrm{h}$, then filtered. The filtrate obtained was collected, and the remaining filtration was soaked again with a new solvent. The process was carried out until the color of the filtrate becomes clear. The ethanol extract was concentrated using a rotary evaporator. Furthermore, the extract was stored for phytochemical screening and animals test. Phytochemical screening test was carried out for alkaloids, phenolics, flavonoids, coumarins, tannins, steroids, saponins, and carotenoids.

\section{Animals test}

Agroup of male mice (8 weeks old, average body weight $[B W]$ 20-35 g) were obtained from Samarinda. The mice were acclimatized in experimental conditions (the light cycle was $12 \mathrm{~L}: 12 \mathrm{D}$, temperature $23 \pm 3^{\circ} \mathrm{C}$, room humidity $50-70 \%$ ), feed and water were provided ad libitum for about 7 days. We followed the ARRIVE (Animal Research: Reporting of in vivo Experiments) as a guideline for conducting research with the animal.

\section{Acute toxicity test}

Ten male mice were divided into two groups, namely, a control group that was given CMC $0.5 \%$ and the extract treatment group dose $2000 \mathrm{mg} / \mathrm{kg} \mathrm{BW}$, which was dissolved in CMC $0.5 \%$ orally. The mice were observed for possible toxicity every hour for the first 6 $h$ and continued to be observed every day for 14 days. Mice were observed as a sign of toxicity to their physical and behavioral changes and recorded the number of mortality to determine $50 \%$ lethal dose $\left(L_{50}\right)$.

\section{Subchronic toxicity test}

Twenty-five male mice each were divided into five groups. The extract was suspended in $0.5 \% \mathrm{CMC}$ with a given volume of $1 \mathrm{~mL} / 100 \mathrm{~g} \mathrm{BW}$. The extract mixture was given orally every day for 28 days. The control group was given $0.5 \% \mathrm{CMC}$, while the treatment groups were treated with various doses extract of 125 , 250,500 , and $1000 \mathrm{mg} / \mathrm{kg} \mathrm{BW}$, respectively. Mice were given standard feed and water ad libitum. The weight of mice was measured once a week. The signs of toxicity and mortality were observed every day. At the end of the treatment, the experimental animals were fasted overnight, then anesthetized and blood was collected in ethylenediaminetetraacetic acid (EDTA) tubes for hematological analysis, while tubes without EDTA for serum biochemical analysis.

\section{analysis \\ Hematology and serum biochemistry}

Hematological analysis of blood such as white blood cell, red blood cell, hemoglobin, hematocrit $(\mathrm{Ht})$, mean corpuscular hemoglobin $(\mathrm{MCH})$ concentration, $\mathrm{MCH}$, mean corpuscular volume (MCV), and platelets was carried out in accordance with the analysis guide for the automatic blood analyzer (Sysmex XS-800i ${ }^{\circledR}$ ). Meanwhile, serum biochemical analysis, blood without EDTA, was centrifuged at $3000 \mathrm{rpm}$ for $10 \mathrm{~min}$. Resulted serum was analyzed for alanine transaminase (ALT), aspartate transaminase (AST), alkaline phosphatase (ALP), gamma-glutamyl transferase, bilirubin, total protein, albumin, creatinine, urea, glucose, cholesterol, triglyceride (TG), and lactate dehydrogenase (LDH) using automatic biochemistry analyzer (7020, Hitachi, Japan). All animals were then sacrificed to determine the weight (g) and relative weight (\%) of the organs such as the heart, lungs, spleen, stomach, liver, testes, and kidneys.

\section{Data analysis}

The results of body, organ and relative organ weight, and hematological and biochemical data were expressed as mean \pm standard error. Data were analyzed using one-way ANOVA and followed by least significant difference (SPSS version 22, SPSS, Inc., USA).

\section{Results}

\section{Phytochemical screening}

The phytochemical analysis of $F$. deltoidea leaves ethanol extract positively contained alkaloids, phenolics, flavonoids, coumarin, and steroids. However, 
other secondary metabolites such as saponins, carotenoids, and tannins were not found. Quantitatively, total phenolics and flavonoids of $F$. deltoidea leaves ethanol extract were $107.6583211 \mu \mathrm{g} \mathrm{GA} / \mathrm{mg}$ and $175.9103641 \mu \mathrm{g} \mathrm{CE} / \mathrm{mg}$. The extract also has antioxidant activities with the $\mathrm{IC}_{50}$ value of $103.7484 \mu \mathrm{g} / \mathrm{mL}$, which classified as a medium category [17].

\section{Acute toxicity test}

In this study, we evaluated the potential for toxicity and an approximate $L_{50}$ of $F$. deltoidea leaves ethanol extract at a dose of $2000 \mathrm{mg} / \mathrm{kg} \mathrm{BW}$ after oral treatment of male mice. The results showed that there were no signs of symptoms of toxicity or behavioral changes such as unhealthy or abnormal behavior and mortality within $72 \mathrm{~h}-14$ days after extract administration. The present findings revealed that an increase in BW of the treatment group was shown no significantly different compared to the control group unless the cumulative weight was decreased (Table 1). This research indicated that the administration of $F$. deltoidea leaf ethanol extract at a dose of $2000 \mathrm{mg} / \mathrm{kg} \mathrm{BW}$ did not affect the BW of mice.

Table 1: Body weight analysis of mice treated orally with the ethanol extract of $F$. deltoidea leaves for 14 days

\begin{tabular}{lll}
\hline Parameters & Acute toxicity & \\
\cline { 2 - 3 } & Control & $2000 \mathrm{mg} / \mathrm{kg} \mathrm{BW}$ \\
\hline Initial weight $(\mathrm{g})$ & $23.340 \pm 0.145$ & $26.158 \pm 1.809$ \\
Final weight $(\mathrm{g})$ & $27.522 \pm 0.689$ & $28.626 \pm 2.092$ \\
BWG $(\mathrm{g})$ & $4.182 \pm 0.633$ & $2.468 \pm 0.344$ \\
BWG $(\%)$ & $15.015 \pm 1.843$ & $8.519 \pm 0.670^{\star}$ \\
\hline Data were represented as Mean \pm SEM, ${ }^{*} \mathrm{p}<0.05$ versus control. F. deltoidea: Ficus deltoidea, BW: Body
\end{tabular}
weight, BWG: Body weight gain.

Further, the results of the index of heart, lungs, spleen, stomach, liver, testes, and kidneys showed that no enlargement of organs in each mice at a dose $2000 \mathrm{mg} / \mathrm{kg} \mathrm{BW}$ except at the relative weight of the left testes, while the right testicular weight was decreased (Table 2). However, since no macroscopic or clinical changes were observed, then no biological significance was associated with it.

\section{Subchronic toxicity}

The current results stated that daily oral administration of $F$. deltoidea leaves ethanol extract $(125,250,500$, and $1000 \mathrm{mg} / \mathrm{kg} \mathrm{BW}$, p.o.) for 28 days did not cause any symptoms of signs of toxicity, changes in behavior, and mortality in mice. The results also found that some mice showed an increase in locomotor activity during the first $30 \mathrm{~min}$ after administration and returned to its normal state within $30 \mathrm{~min}$. This condition may cause by the pressure of the gavage treatment [18]. In addition, no obvious general clinical signs were found during the monitoring period.

BW on male mice did not show significant differences between the treatment group and the
Table 2: The weights $(\mathrm{g})$ and relative weights $(\%)$ of the organ of male mice treated orally with the ethanol extract of F. deltoidea leaves for 14 days

\begin{tabular}{llll}
\hline Organs & Unit & Acute toxicity & \\
\cline { 3 - 4 } & & Control & $\mathbf{2 0 0 0 ~} \mathbf{~ m g} / \mathbf{k g ~ B W}$ \\
\hline Heart & $(\mathrm{g})$ & $0.143 \pm 0.012$ & $0.139 \pm 0.009$ \\
& $(\%)$ & $0.521 \pm 0.045$ & $0.502 \pm 0.066$ \\
Pulmo & $(\mathrm{g})$ & $0.174 \pm 0.013$ & $0.193 \pm 0.023$ \\
& $(\%)$ & $0.637 \pm 0.055$ & $0.698 \pm 0.110$ \\
Liver & $(\mathrm{g})$ & $1.464 \pm 0.050$ & $1.613 \pm 0.168$ \\
& $(\%)$ & $5.341 \pm 0.272$ & $5.850 \pm 0.890$ \\
Spleen & $(\mathrm{g})$ & $0.225 \pm 0.048$ & $0.211 \pm 0.055$ \\
& $(\%)$ & $0.827 \pm 0.183$ & $0.772 \pm 0.223$ \\
Ventriculus & $(\mathrm{g})$ & $0.556 \pm 0.075$ & $0.812 \pm 0.186$ \\
& $(\%)$ & $2.045 \pm 0.300$ & $2.915 \pm 0.667$ \\
Kidney (left) & $(\mathrm{g})$ & $0.198 \pm 0.008$ & $0.229 \pm 0.019$ \\
& $(\%)$ & $0.719 \pm 0.023$ & $0.835 \pm 0.124$ \\
Kidney (right) & $(\mathrm{g})$ & $0.200 \pm 0.007$ & $0.228 \pm 0.019$ \\
& $(\%)$ & $0.727 \pm 0.011$ & $0.831 \pm 0.120$ \\
Testis (left) & $(\mathrm{g})$ & $0.123 \pm 0.014$ & $0.117 \pm 0.024$ \\
& $(\%)$ & $0.155 \pm 0.026$ & $0.411 \pm 0.079^{*}$ \\
Testis (right) & $(\mathrm{g})$ & $0.451 \pm 0.059$ & $0.117 \pm 0.013^{*}$ \\
& $(\%)$ & $0.569 \pm 0.100$ & $0.416 \pm 0.045$ \\
\hline Data were represented as Mean \pm SEM, ${ }^{*}$ p $<0.05$ versus control. F. deltoidea: Ficus deltoidea, BW: Body
\end{tabular}
weight.

control group during the treatment period. Meanwhile, the relative weight did not also indicate a significant difference, except at the dose of 125 and $1000 \mathrm{mg} / \mathrm{kg}$ BW, which showed a decrease in the percentage of relative weight (Table 3 ).

Furthermore, there is no significant difference $(p>0.05)$ of all organ weight $(g)$ and relative organ between the treatment group and the control group, including the heart, lungs, liver, spleen, stomach, kidneys, and testes at each dose level (Table 4). However, the relative hepatic weight of mice treated with extracts at a dose of 125 and $500 \mathrm{mg} / \mathrm{kg} \mathrm{BW}$ found significantly decreased. The heart, lungs, spleen, stomach, kidneys, and testicles did not change after subchronic treatment in male mice. However, all minor fluctuations in the weight value of this relative organ remain within the normal range and are sporadic. No significant changes have been logically observed in the organ between the control group and the treatment group. These results indicated that for 4 weeks, it has no toxic effect on male mice.

\section{analysis}

Hematology and blood biochemical

The effects of $F$. deltoidea leaf ethanol extract on some hematological parameters of the treatment and control are presented in Table 5. The results showed that the extract administration during the 28-day trial period did not cause statistically significant changes ( $p>0.05$ ) on the hematological parameters compared to the control except for the dose of $250 \mathrm{mg} / \mathrm{kg} \mathrm{BW}$, the $\mathrm{Ht}$ found significantly increased, while the MCV was decreased in comparison with control. Meanwhile, oral administration of the ethanol extract of $F$. deltoidea leaves for 28 days did not cause significant changes $(p>0.05)$ on serum biochemical parameters compared to the control. However, there is a significant increase in AST and ALP in the serum of mice treated with a dose of $1000 \mathrm{mg} / \mathrm{kg} \mathrm{BW}$ (Table 6). 
Table 3: Body weight and body weight gain of mice treated orally for 28 days with ethanol extract of $F$. deltoidea leaves

\begin{tabular}{|c|c|c|c|c|c|}
\hline \multirow[t]{2}{*}{ Parameter } & \multicolumn{5}{|c|}{ Subchronic toxicity treatment (mg/kg BW) } \\
\hline & Control & 125 & 250 & 500 & 1000 \\
\hline Initial weight (g) & $16.048 \pm 0.899$ & $29.236 \pm 2.109$ & $19.166 \pm 2.644$ & $20.714 \pm 0.566$ & $26.040 \pm 3.228$ \\
\hline Final weight $(\mathrm{g})$ & $24.766 \pm 1.645^{\mathrm{a}}$ & $33.936 \pm 1.225^{b}$ & $25.004 \pm 2.886^{\mathrm{a}, \mathrm{b}}$ & $28.336 \pm 0.405^{\mathrm{a}, \mathrm{b}}$ & $31.832 \pm 3.115^{\mathrm{a}, \mathrm{b}}$ \\
\hline BWG (g) & $8.718 \pm 1.188^{\mathrm{a}}$ & $4.700 \pm 1.109^{b}$ & $5.838 \pm 0.420^{\mathrm{a}, \mathrm{b}}$ & $7.622 \pm 0.244^{\mathrm{a}, \mathrm{b}}$ & $5.792 \pm 0.595^{\mathrm{a}, \mathrm{b}}$ \\
\hline BWG (\%) & $34.627 \pm 3.395^{\mathrm{a}}$ & $14.214 \pm 1.109^{b}$ & $24.067 \pm 2.165^{\mathrm{a}, \mathrm{b}, \mathrm{c}}$ & $26.945 \pm 1.113^{\mathrm{a}, \mathrm{c}}$ & $19.150 \pm 3.209^{b, c}$ \\
\hline
\end{tabular}

Data were represented as Mean \pm SE. The one-way ANOVA followed by LSD test was performed to obtain significantly different among the groups of treatments. The different letter superscripts (a, b, c) in the same row

indicate significantly different $\mathrm{p}<0.05$ versus control. BW: Body weight, BWG: Body weight gain, LSD: Least significant difference.

Table 4: Organ weights and relative organ weights of male mice treated orally with ethanol extract of $F$. deltoidea leaves for 28 days

\begin{tabular}{|c|c|c|c|c|c|c|}
\hline \multirow[t]{2}{*}{ Organ } & \multirow[t]{2}{*}{ Unit } & \multicolumn{5}{|c|}{ Subchronic toxicity treatment (mg/kg BW) } \\
\hline & & Control & 125 & 250 & 500 & 1000 \\
\hline \multirow[t]{2}{*}{ Heart } & (g) & $0.420 \pm 0.262$ & $0.189 \pm 0.013$ & $0.151 \pm 0.012$ & $0.253 \pm 0.097$ & $0.159 \pm 0.019$ \\
\hline & (\%) & $2.039 \pm 1.439$ & $0.563 \pm 0.054$ & $0.621 \pm 0.042$ & $0.894 \pm 0.345$ & $0.500 \pm 0.047$ \\
\hline \multirow[t]{2}{*}{ Pulmo } & (g) & $0.218 \pm 0.015$ & $0.256 \pm 0.009$ & $0.253 \pm 0.022$ & $0.298 \pm 0.090$ & $0.255 \pm 0.025$ \\
\hline & (\%) & $0.899 \pm 0.086$ & $0.760 \pm 0.050$ & $1.067 \pm 0.154$ & $1.054 \pm 0.320$ & $0.829 \pm 0.098$ \\
\hline \multirow[t]{2}{*}{ Liver } & (g) & $1.486 \pm 0.127$ & $1.491 \pm 0.036$ & $1.527 \pm 0.052$ & $1.287 \pm 0.075$ & $1.646 \pm 0.199$ \\
\hline & (\%) & $6.110 \pm 0.628^{\mathrm{a}, \mathrm{b}}$ & $4.408 \pm 0.141^{\mathrm{b}}$ & $6.384 \pm 0.634^{\mathrm{a}}$ & $4.540 \pm 0.255^{\mathrm{b}}$ & $5.144 \pm 0.256^{\mathrm{a}, \mathrm{t}}$ \\
\hline \multirow{2}{*}{ Spleen } & (g) & $0.202 \pm 0.041$ & $0.222 \pm 0.020$ & $0.298 \pm 0.041$ & $0.233 \pm 0.096$ & $0.301 \pm 0.072$ \\
\hline & $(\%)$ & $0.842 \pm 0.184$ & $0.654 \pm 0.057$ & $1.234 \pm 0.194$ & $0.822 \pm 0.340$ & $0.901 \pm 0.144$ \\
\hline \multirow[t]{2}{*}{ Ventriculus } & (g) & $0.863 \pm 0.146$ & $0.536 \pm 0.086$ & $0.635 \pm 0.123$ & $0.520 \pm 0.103$ & $0.505 \pm 0.080$ \\
\hline & (\%) & $3.631 \pm 0.726$ & $1.614 \pm 0.311$ & $2.810 \pm 0.756$ & $1.840 \pm 0.368$ & $1.558 \pm 0.161$ \\
\hline \multirow[t]{2}{*}{ Kidney (left) } & (g) & $0.201 \pm 0.018$ & $0.257 \pm 0.024$ & $0.214 \pm 0.021$ & $0.314 \pm 0.091$ & $0.232 \pm 0.031$ \\
\hline & (\%) & $0.817 \pm 0.056$ & $0.753 \pm 0.051$ & $0.875 \pm 0.091$ & $1.108 \pm 0.323$ & $0.716 \pm 0.045$ \\
\hline \multirow[t]{2}{*}{ Kidney (right) } & (g) & $0.196 \pm 0.019$ & $0.255 \pm 0.019$ & $0.334 \pm 0.105$ & $0.325 \pm 0.090$ & $0.232 \pm 0.027$ \\
\hline & $(\%)$ & $0.791 \pm 0.045$ & $0.748 \pm 0.039$ & $1.445 \pm 0.531$ & $1.149 \pm 0.319$ & $0.724 \pm 0.046$ \\
\hline \multirow[t]{2}{*}{ Testis (left) } & (g) & $0.106 \pm 0.006$ & $0.129 \pm 0.007$ & $0.091 \pm 0.016$ & $0.230 \pm 0.101$ & $0.116 \pm 0.015$ \\
\hline & $(\%)$ & $0.436 \pm 0.045$ & $0.381 \pm 0.011$ & $0.367 \pm 0.057$ & $0.813 \pm 0.359$ & $0.359 \pm 0.027$ \\
\hline \multirow{2}{*}{ Testis (right) } & (g) & $0.106 \pm 0.005$ & $0.131 \pm 0.006$ & $0.106 \pm 0.020$ & $0.213 \pm 0.094$ & $0.126 \pm 0.019$ \\
\hline & (\%) & $0.435 \pm 0.031$ & $0.388 \pm 0.022$ & $0.435 \pm 0.080$ & $0.753 \pm 0.334$ & $0.391 \pm 0.046$ \\
\hline
\end{tabular}

Data were expressed as Mean \pm SE. The one-way ANOVA followed by LSD test. The different letter indexes (a, b, c) in the same row indicate significantly different $p<0.05$ versus control. F. deltoidea: Ficus deltoidea,

BW: Body weight, LSD: Least significant difference.

Table 5: Hematological parameters of male mice treated orally with the ethanol extract of Ficus deltoidea leaves for 28 days

\begin{tabular}{|c|c|c|c|c|c|}
\hline \multirow[t]{2}{*}{ Parameters } & \multicolumn{5}{|c|}{ Treatment (mg/kg BW) } \\
\hline & Control & 125 & 250 & 500 & 1000 \\
\hline WBC $\left(10^{3} / \mu \mathrm{L}\right)$ & $1.65 \pm 0.31$ & $1.82 \pm 0.14$ & $1.83 \pm 0.45$ & $2.25 \pm 0.59$ & $2.03 \pm 0.28$ \\
\hline $\operatorname{RBC}\left(10^{6} / \mu \mathrm{L}\right)$ & $0.96 \pm 0.31$ & $0.81 \pm 0.25$ & $1.55 \pm 0.26$ & $1.08 \pm 0.15$ & $0.88 \pm 0.15$ \\
\hline $\mathrm{Hb}(\mathrm{g} / \mathrm{dL})$ & $7.60 \pm 0.51$ & $7.88 \pm 0.14$ & $7.38 \pm 0.47$ & $8.20 \pm 0.38$ & $7.88 \pm 0.25$ \\
\hline $\mathrm{Ht}(\%)$ & $3.28 \pm 0.41^{\mathrm{a}}$ & $4.42 \pm 1.05^{\mathrm{a}, \mathrm{b}}$ & $7.50 \pm 0.96^{\mathrm{b}}$ & $5.74 \pm 0.69^{\mathrm{a}, \mathrm{b}}$ & $5.48 \pm 0.95^{\mathrm{a}, \mathrm{b}}$ \\
\hline MCV (fL) & $60.32 \pm 1.46^{a}$ & $49.76 \pm 1.25^{b}$ & $42.52 \pm 2.53^{\mathrm{c}}$ & $60.40 \pm 0.94^{\mathrm{a}}$ & $61.44 \pm 0.97^{\mathrm{a}}$ \\
\hline $\mathrm{MCH}(\mathrm{pg})$ & $141.80 \pm 2.19$ & $158.14 \pm 9.66$ & $127.70 \pm 6.79$ & $138.54 \pm 14.03$ & $158.96 \pm 11.82$ \\
\hline $\mathrm{MCHC}(\mathrm{g} / \mathrm{dL})$ & $240.86 \pm 1.83$ & $239.06 \pm 47.20$ & $184.32 \pm 24.35$ & $153.66 \pm 16.99$ & $181.80 \pm 20.11$ \\
\hline $\operatorname{PLT}\left(10^{3} / \mu \mathrm{L}\right)$ & $2499.00 \pm 14.71$ & $3795.60 \pm 421.92$ & $2507.00 \pm 683.33$ & $3782.40 \pm 307.42$ & $2891.40 \pm 213.88$ \\
\hline
\end{tabular}

Pata were expressed as Mean \pm SE. The one-way ANOVA followed by LSD test. The different letter indexes (a, b, c) in the same row indicate significantly different $p<0.05$ versus control. MCHC: Mean corpuscular 213.88

hemoglobin concentration, MCH: Mean corpuscular hemoglobin, WBC: White blood cell, RBC: Red blood cell, Hb: Hemoglobin, Ht: Hematocrit, PLT: Platelet, MCV: Mean corpuscular volume, LSD: Least significant difference,

F. deltoidea: Ficus deltoidea, BW: Body weight.

Table 6: Biochemical serum parameters of male mice treated orally with the ethanol extract of $F$. deltoidea leaves for 28 days

\begin{tabular}{|c|c|c|c|c|c|}
\hline \multirow[t]{2}{*}{ Parameters } & \multicolumn{5}{|c|}{ Treatment (mg/kg BW) } \\
\hline & Control & 125 & 250 & 500 & 1000 \\
\hline Glu (mg/dL) & $145.00 \pm 8.51^{a, b}$ & $117.20 \pm 12.56^{\mathrm{a}, \mathrm{b}}$ & $130.40 \pm 13.54^{a, b}$ & $108.80 \pm 5.08^{b}$ & $171.20 \pm 23.53^{\mathrm{a}}$ \\
\hline AST (U/L) & $244.60 \pm 13.12^{\mathrm{a}}$ & $265.60 \pm 52.77^{\mathrm{a}, \mathrm{b}}$ & $227.20 \pm 18.62^{\mathrm{a}}$ & $567.00 \pm 92.36^{b}$ & $1155.80 \pm 125.22^{c}$ \\
\hline $\operatorname{ALT}(\mathrm{U} / \mathrm{L})$ & $87.20 \pm 13.36$ & $116.80 \pm 11.01$ & $116.00 \pm 24.58$ & $193.00 \pm 49.73$ & $186.80 \pm 48.71$ \\
\hline $\operatorname{ALP}(\mathrm{U} / \mathrm{L})$ & $75.60 \pm 4.01^{\mathrm{a}}$ & $95.00 \pm 10.38^{\mathrm{a}}$ & $77.80 \pm 11.33^{\mathrm{a}}$ & $96.60 \pm 7.00^{\mathrm{a}}$ & $147.20 \pm 9.87^{b}$ \\
\hline BiL-T $(\mu \mathrm{M})$ & $0.10 \pm 0.01^{\mathrm{a}}$ & $0.07 \pm 0.01^{\mathrm{a}, \mathrm{b}}$ & $0.05 \pm 0.01^{\mathrm{b}}$ & $0.07 \pm 0.01^{\mathrm{a}, \mathrm{b}}$ & $0.08 \pm 0.01^{\mathrm{a}, \mathrm{b}}$ \\
\hline BiL-D $(\mu \mathrm{M})$ & $0.03 \pm 0.01$ & $0.03 \pm 0.00$ & $0.03 \pm 0.00$ & $0.02 \pm 0.00$ & $0.04 \pm 0.01$ \\
\hline TP (g/L) & $5.18 \pm 0.30^{\mathrm{a}}$ & $6.08 \pm 0.19^{b}$ & $5.92 \pm 0.13^{\mathrm{a}, \mathrm{b}}$ & $5.46 \pm 0.21^{\mathrm{a}, \mathrm{b}}$ & $5.56 \pm 0.13^{\mathrm{a}, \mathrm{b}}$ \\
\hline $\operatorname{ALB}(g / L)$ & $2.94 \pm 0.09$ & $3.30 \pm 0.26$ & $3.34 \pm 0.12$ & $3.34 \pm 0.17$ & $3.16 \pm 0.09$ \\
\hline $\mathrm{TC}(\mathrm{mg} / \mathrm{dL})$ & $90.20 \pm 6.41$ & $109.60 \pm 6.32$ & $95.80 \pm 1.85$ & $91.20 \pm 7.97$ & $86.60 \pm 6.93$ \\
\hline $\mathrm{UA}(\mathrm{mg} / \mathrm{dL})$ & $3.22 \pm 0.29^{\mathrm{a}, \mathrm{b}}$ & $2.20 \pm 0.25^{\mathrm{b}}$ & $3.32 \pm 0.23^{\mathrm{a}, \mathrm{b}}$ & $3.22 \pm 0.45^{\mathrm{a}, \mathrm{b}}$ & $3.60 \pm 0.30^{\mathrm{a}}$ \\
\hline BUN (mg/dL) & $42.50 \pm 2.15^{\mathrm{a}}$ & $65.96 \pm 3.96^{\mathrm{b}}$ & $44.04 \pm 3.17^{\mathrm{a}, \mathrm{b}}$ & $47.46 \pm 8.55^{\mathrm{a}, \mathrm{b}}$ & $62.94 \pm 6.27^{\mathrm{a}, \mathrm{b}}$ \\
\hline $\mathrm{Cr}(\mathrm{mg} / \mathrm{dL})$ & $0.04 \pm 0.01^{\mathrm{a}}$ & $0.011 \pm 0.01^{b}$ & $0.07 \pm 0.01^{\mathrm{a}, \mathrm{b}}$ & $0.09 \pm 0.01^{b}$ & $0.06 \pm 0.01^{a, b}$ \\
\hline LDH (U/L) & $1323.20 \pm 101.04^{a, b}$ & $1479.80 \pm 215.59^{\mathrm{a}, \mathrm{b}}$ & $1481.80 \pm 127.68^{\mathrm{a}, \mathrm{b}}$ & $1584.80 \pm 120.21^{\mathrm{b}}$ & $817.80 \pm 214.97^{\mathrm{a}}$ \\
\hline
\end{tabular}

Data were expressed as Mean \pm SE. The one-way ANOVA followed by LSD test. The different letter superscripts (a, b, c) in the same row indicate significantly different p<0.05 versus control. Glu: Glukosa, AST: Asparta
transaminase, ALT: Alanine transaminase, ALP: Alkaline phosphatase, Bil-T: Bilirubin total, Bil-D: Bilirubin direct, TP: Total protein, ALB: Albumin, TC: Total cholesterol, TG: Triglyceride, UA: Uric acid, BUN: Blood urea

nitrogen, Cr: Creatinine, LDH: Lactate dehydrogenase, F. deltoidea: Ficus deltoidea, BW: Body weight, LSD: Least significant difference.

\section{Discussion}

The plant has long been used for human needs for food making and medicinal herbs. It is usually accepted as very safe compounds to consume and contains some important secondary metabolites [19], [20], [21], [22]. The secondary metabolite or bioactive compounds (phytochemicals) of phenolic, such as existing flavonoids in plants, have been reported to be responsible for various biological processes in the body [23], [24], [25], [26]. Although bioactive compound from plant including flavonoid is widely used, the use of plants itself may be able to cause unexpected effects of toxicity. The toxicity might be derived from several plant compound that causes hematotoxic [27] and hepatotoxic [28], which can provoke insertional and carcinogenesis [29], [30]. Recently, there is still a lack of scientific data evidence on the toxicity and safety of many plants. Therefore, 
the scientific evaluation of the effectiveness, as well as the safety of herbal medicine, is urgent to be done. Meanwhile, the first priority in herbal research with toxicological studies to determine the toxicity of the product and choose a safe dose in humans using various experimental models needs to be conducted [31].

The acute toxicity test in animals can be used to obtain the hazard classification requirement of $L D_{50}$ value. The acute toxicity is usually to be the first step to be done and can provide preliminary information about the toxic action of a substance, determining the dose in animals [32]. It is the basis that the acute toxicity assessment of the ethanol extract of $F$. deltoidea leaves was carried out in mice. In general, abnormal changes in general behavior and BW have been used as critical parameters for objective evaluation of the test substance effect on experimental animals because these changes are often the first sign of toxicity [33], [34].

The present findings stated that mice treated with the ethanol extract of $F$. deltoidea leaves in the acute and subchronic toxicity did not either cause mortality or even did not appear to have abnormal changes in general behavior, a significant variation of the weight associated with the treatment of extracts, or food/water intake as a sign of critical poisoning in test animals. Therefore, it can be assumed that the $L D_{50}$ of the extract is $>2000 \mathrm{mg} / \mathrm{kg}$, which suggests that extracts are generally considered as nontoxic in acute ingestion, based on the method of classification of acute toxicity [35]. Moreover, the present results regarding $L D_{50}$ evaluation revealed that a single oral dose $(2000 \mathrm{mg} / \mathrm{kg} \mathrm{BW})$ did not cause mortality in $72 \mathrm{~h}$ and during 14 days of observation. These results indicated that acute exposure to the ethanol extract of F. deltoidea leaves did not cause toxic effects, and the value of $L D_{50}$ was considered to be $>2000 \mathrm{mg} / \mathrm{kg} \mathrm{BW}$ in mice that are harmless in acute doses [36].

During this subchronic test, all animals were active and responded positively to stimuli. There were no mortality, behavioral changes and clinical signs of localized or systemic toxic effects were observed. In addition to mortality as a clear sign of toxicity, there are other variables that may exhibit side effects such as BW during clinical treatment and signs of toxicity [15]. Changes in BW function as an indication of sensitive animal health status are usually used as a tool, indicator, and marker of side effects in toxicological investigation [37], while the weight of the organs is relative to indicate pathological changes in the disturbed organs [38]. The current results in subchronic toxicity studies revealed that BW showed no significant changes after administration of the extract for 28 days in comparison to the control group. Meanwhile, relative weight gain also did not show a significant difference, except in mice that treat with ethanolic extract of F. deltoidea leaves at the dose of 125 and $1000 \mathrm{mg} / \mathrm{kg}$ BW which relative weight gain was found a significant decrease. The present finding is supported by the previous research stated that the leaves of methanolic extract of $F$. deltoidea at a dose of $200 \mathrm{mg} / \mathrm{kg}$ did not cause abnormal changes in liver and kidney function in subchronic toxicity study [39]. This is likely due to some external factors affecting this group in particular, such as the struggle for domination (the struggle for social hierarchy, the characteristics of a male beast), or the monotonous of a diet that can lead to decreased feed intake. Furthermore, most of the relative organ weight seems to be unaffected by the extract treatment except at the relative hepatic weight of the extract at the dose of 125 and $500 \mathrm{mg} / \mathrm{kg}$ BW which decreased in comparison to the control. The difference in weight of internal organs may be due to variations in the size of internal organs and/or BW of animals [40].

To evaluate the symptoms of organ disorders, various hematological and biochemical blood parameters are also measured in male mice. Repeated administration of a substance to subchronic toxicity can cause temporary or permanent damage to the hematopoietic system. Evaluation of hematological parameters is one of the systems that are very sensitive to toxic compounds and can be used as an indicator to determine the effect of toxic substances and provide information about the pathophysiology of mammals [41], [42].

The current results showed that there was an increase $\mathrm{Ht}$ but decreased in MCV of mice treated with $250 \mathrm{mg} / \mathrm{kg} \mathrm{BW}$ dose. This condition is likely irrelevant because they were in the normal physiological range [43]. These changes were not dose dependent because it was only observed in groups treated with $250 \mathrm{mg} / \mathrm{kg} \mathrm{BW}$ dose, while at higher dosages were not found. Since no corresponding changes were observed in other parameters, significant changes in HCT and $\mathrm{MCV}$ were not related to the treatment. Further, there was no regularity between increasing the dose and the increase in toxic effects. These results are similar to the previous findings, conducted by Bo Li et al. [44] who found that some blood hematology parameters do not have a consistent pattern between increasing the dose with the change in hematological parameters and the time of measurement. This unfixed pattern is due to some variations of a small number of animal in one group and cannot be claimed that the test sample provided a toxic effect on the referred parameter.

To investigate systemic toxicity or target organs inflicted by the substances being tested, blood serum biochemical test is also needed for further assessment. Serum biochemical test on experimental animal studies aims to determine the toxic effects, especially on the kidneys and liver [45], [46]. In toxicity study, the assessment of liver and kidney function is very important because these two organs are the primary internal organs in the body that has some important functions for the survival of organisms [47]. The results of the present study appeared that AST and ALP blood serum of the mice in the group $1000 \mathrm{mg} / \mathrm{kg} / \mathrm{BW}$ was significantly higher than control. Balogunand and Ashafa [48] revealed that 
the increase AST and ALP at a high-dose extract might be having a hepatotoxic effect, while an increase in ALP may occur obstruction of the bile duct in the liver. In addition to these two parameters, it seems that there were slightly biochemical differences that were not constant in all doses tested versus control and inconsistent between the dose and the observation period, considering as an incidental. Moreover, some parameters for each animal were found slightly increase or decrease in the treatment group compared to the control group, including the total protein, total bilirubin, urea, creatinine, uric acid, TG, glucose, and LDH. Meanwhile, the ALT, ALB, and cholesterol parameters were found no significantly different compared to the controls. Regardless of its significance, these data indicated that there was no apparent dose-response relationship, and all small fluctuations in these parameters were within the normal range of testing laboratories. Therefore, these variations were no relevance to the clinical significance or toxic effects of extracts but rather than the physiological variability of the animal itself. In addition, the effect was not dose dependent, and it is not accompanied by clinical signs or symptoms [49].

\section{Conclusion}

This study shows that acute and subchronic oral administration of the ethanol extract of $F$. deltoidea leaves for male mice does not induce clinical symptoms of toxicity or cause mortality. The $\mathrm{LD}_{50}$ from the ethanol extract of F. deltoidea leaves for mice $>2000 \mathrm{mg} / \mathrm{kg}$ is considered as practically non-toxic based on the BW, relative BW, hematological, and blood biochemical analysis.

\section{Acknowledgment}

All authors grateful thank to Directorate General of Higher Education Ministry of Research Technology and Higher Education, Republic Indonesia for the grant, contract number 200/UN.17.41/KL/2019, financial year 2019. The authors also extended thanks to Faculty of Mathematics and Natural Sciences, Mulawarman University, East Kalimantan, Samarinda, for any kind of support.

\section{References}

1. Ekor M. The growing use of herbal medicines: Issues relating to adverse reactions and challenges in monitoring safety. Front
Pharmacol. 2014;4:177. https://doi.org/10.3389/fphar.2013.00177 PMid:24454289

2. Azis NA, Agarwal $\mathrm{R}$, Ismail NM, Ismail $\mathrm{NH}$, Kamal MSA, Radjeni $\mathrm{Z}$, et al. Blood pressure lowering effect of Ficus deltoidea var kunstleri in spontaneously hypertensive rats: Possible involvement of renin-angiotensin-aldosterone system, endothelial function and anti-oxidant system. Mol Biol Rep. 2019;46(3):2841-9. https://doi.org/10.1007/ s11033-019-04730-w

PMid:30977084

3. Afzan A, Kasim N, Ismail NH, Azmi N, Ali AM, Mat N, et al. Differentiation of Ficus deltoidea varieties and chemical marker determination by UHPLC-TOFMS metabolomics for establishing quality control criteria of this popular Malaysian medicinal herb. Metabolomics. 2019;15(3):35. https://doi.org/10.1007/ s11306-019-1489-2

PMid:30830457

4. Fauzi F, Widodo H. Aphrodisiac plants used by Dayak ethnic in Central Kalimantan Province, Indonesia. Biodivers J Biol Divers. 2019;20(7):1859-65. https://doi.org/10.13057/biodiv/d200710

5. Sundari S, Wardah W. Ethnobotany study of dayak society medicinal plants utilization in Uut Murung district, Murung Raya Regency, Central Kalimantan. In: The 2018 International Conference on Biosphere Reserve: The Role of Stakeholders in Mainstreaming Natural Resources Related to Agenda 2030, Sustainable Development Goals. Palembang, South Sumatera, Indonesia: IOP Publishing; 2019. p. 012005. https://doi. org/10.1088/1755-1315/298/1/012005

6. Salleh N, Ahmad VN. In vitro effect of Ficus deltoidea on the contraction of isolated rat's uteri is mediated via multiple receptors binding and is dependent on extracellular calcium. BMC Complement Altern Med. 2013;13:359. https://doi. org/10.1186/1472-6882-13-359

PMid:24330515

7. Mustaffa NA, Hasham R, Sarmidi MR. An in vitro study of wound healing activity of Ficus deltoidea Leaf extract. J Teknol. 2015;77(3):1-6. https://doi.org/10.11113/jt.v77.6008

8. Asis J, Yusoff N, Nashriyah M. Allelopathic assesments of Ficus deltoidea jack varieties and Ficus microcarpa L.f. (Moraceae) on Lactuca sativa L. Seed. J Agrobiotechnol. 2018;9(1S):214-21.

9. Isa MN, Ajit A, Naila A, Sulaiman A. Effect of Microwave Assisted Hydrodistillation Extraction on Extracts of Ficus deltoidea Materials Today. Vol. 5. Proceedings; 2018. p. 21772-9. https:// doi.org/10.1016/j.matpr.2018.07.031

10. Bodeker G, Shekar S. Health and Beauty from the Rainforest: Malaysian Traditions of Ramuan. USA: Didier Millet, Csi; 2009.

11. Neergheen-Bhujun VS. Underestimating the toxicological challenges associated with the use of herbal medicinal products in developing countries. Biomed Res Int. 2013;2013:804086. https://doi.org/10.1155/2013/804086 PMid:24163821

12. Upton R, Graff A, Jolliffe G, Länger R, Williamson E. American Herbal Pharmacopoeia: Botanical Pharmacognosy-Microscopic Characterization of Botanical Medicines. USA: CRC Press; 2016. https://doi.org/10.1201/b10413

13. Yau WP, Goh CH, Koh HL. Quality Control and Quality Assurance of Phytomedicines: Key Considerations, Methods, and Analytical Challenges USA: John Wiley \& Sons, Inc.; 2015. https://doi.org/10.1002/9781119006039.ch2

14. Schuppan D, Dayan AD, Charlesworth FA. The Contribution of Acute Toxicity Testing to the Evaluation of Pharmaceuticals. Netherland: Springer; 2014. https://doi. org/10.1007/978-3-642-70390-4_10

15. Traesel GK, de Souza JC, de Barros AL, Souza MA, Schmitz WO, Muzzi RM, et al. Acute and subacute (28 days) oral toxicity assessment of the oil extracted from Acrocomia 
aculeata pulp in rats. Food Chem Toxicol. 2014;74:320-25. https://doi.org/10.1016/j.fct.2014.10.026

PMid:25445758

16. Yang M, Wu Z, Wang Y, Kai G, Singor Njateng GS, Cai S, et al. Acute and subacute toxicity evaluation of ethanol extract from aerial parts of Epigynum auritum in mice. Food Chem Toxicol. 2019;131:110534. https://doi.org/10.1016/j.fct.2019.05.042 PMid:31150781

17. Molyneux P. The use of the stable free radical diphenylpicrylhydrazyl (DPPH) for estimating antioxidant activity. Songklanakarin J Sci Technol. 2004;26(2):211-9.

18. Brown AP, Dinger N, Levine BS. Stress produced by gavage administration in the rat. Contemp Top Lab Anim Sci. 2000;39(1):17-21.

PMid:11178310

19. Dung NT, Kim JM, Kang SC. Chemical composition, antimicrobial and antioxidant activities of the essential oil and the ethanol extract of Cleistocalyx operculatus (Roxb.) Merr and Perry buds. Food Chem Toxicol. 2008;46(12):3632-9. https:// doi.org/10.1016/j.fct.2008.09.013 PMid:18838098

20. Zhang QH, Zhang L. research advance in chemical composition and pharmacological action of Chrysanthemum morifolium. Food and Drug. 2007;2:224-6

21. Zhao L, Yang L, Liu Y, Li C, Kang W. Antimicrobial activity of seven species Chrysanthemum morifolium ramat cultivated in kaifeng. Mod Pharm Res. 2009;2:82-5.

22. Sun $\mathrm{W}$, Shahrajabian $\mathrm{MH}$, Cheng Q. Anise (Pimpinella anisum L.), a dominant spice and traditional medicinal herb for both food and medicinal purposes. Cogent Biol. 2019;5(1673688):1-25. https:// doi.org/10.1080/23312025.2019.1673688

23. Chen X, Gu N, Xue C, Li BR. Plant flavonoid taxifolin inhibits the growth, migration and invasion of human osteosarcoma cells. Mol Med Rep. 2018;17(2):3239-45. https://doi.org/10.3892/ mmr.2017.8271

PMid:29257319

24. Khalid M, Bilal M, Huang DF. Role of flavonoids in plant interactions with the environment and against human pathogens-a review. J Integr. 2019;18(1):211-30.

25. Perez-Vizcaino F, Fraga CG. Research trends in flavonoids and health. Arch Biochem Biophys. 2018;646:107-12 PMid:29580946

26. Vicente O, Boscaiu M. Flavonoids: Antioxidant compounds for plant defence and for a healthy human diet. Not Bot Horti Agrobo. 2018;46(1):14-21. https://doi.org/10.15835/nbha46110992

27. Mudimba TN, Maitho T, Mbaria J, Taderera T. Hematotoxicity assessment of phytochemicals from aqueous leaf extracts of Carpobrotus edulis. J Phytopharmacol. 2019;8(4):173-56. https://doi.org/10.31254/phyto.2019.8405

28. El-Sayed MA, Shaltot O, Yousef MI, El-Difrawy EA. protective effect of aerial parts of Portulaca oleracea and Ficus carica Leaves against diclofenac-sodium induced hepatotoxicity in rats. J Food Nutr Sci. 2019;7(1):1-7. https://doi.org/10.11648/j. jfns.20190701.11

29. Michalowicz J, Duda W. Phenols sources and toxicity. Pol J Environ. 2007;16(3):347-62.

30. Ames BN, Profet M, Gold LS. Dietary Carcinogens and Mutagens from Plants. USA: CRC Press; 2018.

31. Farsi E, Shafaei A, Hor SY, Ahamed MB, Yam MF, Asmawi MZ, et al. Genotoxicity and acute and subchronic toxicity studies of a standardized methanolic extract of Ficus deltoidea leaves. Clinics (Sao Paulo). 2013;68(6):865-75. https://doi.org/10.6061/ clinics/2013(06)23

PMid:23778480

32 Ukwuani A, Abubakar M, Hassan S, Agaie B. Toxicological studies of hydromethanolic leaves extract of Grewia crenata. Int J Pharm Sci Drug Res. 2012;4(4):4245-9.

33. Liju VB, Jeena K, Kuttan R. Acute and subchronic toxicity as well as mutagenic evaluation of essential oil from turmeric (Curcuma longa L). Food Chem Toxicol. 2013;53:52-61. https:// doi.org/10.1016/j.fct.2012.11.027 PMid:23201370

34. Sireeratawong S, Lertprasertsuke N, Srisawat U, Thuppia A Ngamjariyawat A, Suwanlikhid N, et al. Acute and subchronic toxicity study of the water extract from root of Sida rhombifolia Linn. In rate. Songklanakarin J Sci Technol. 2008;30(6):729-37.

35. Duan W, Liang X. Technical Guidelines Assembly of Veterinary Medicine Research. Beijing: Chemical Industry Press; 2011.

36. Kifayatullah M. Toxicological investigation of ethanolic extract of Epipremnum aureum in rodents. J Appl Pharma Sci. 2015;5(2):557-61. http://doi.org/10.7324/JAPS.2015.58.S9

37. El Hilaly J, Israili ZH, Lyoussi B. Acute and chronic toxicological studies of Ajuga iva in experimental animals. J Ethnopharmacol. 2004;91(1):43-50. https://doi.org/10.1016/j.jep.2003.11.009 PMid:15036466

38. Li IC, Chen YL, Lee LY, Chen WP, Tsai YT, Chen CC, et al Evaluation of the toxicological safety of erinacine A-enriched Hericium erinaceus in a 28-day oral feeding study in spraguedawley rats. Food Chem Toxicol. 2014;70:61-7. https://doi. org/10.1016/j.fct.2014.04.040 PMid:24810469

39. Ilyanie $\mathrm{Y}$, Wong TW, Choo CY. Evaluation of hypoglycemic activity and toxicity profiles of the leaves of Ficus deltoidea in rodents. J Complement Integr Med. 2011;8:1-16. https://doi org/10.2202/1553-3840.1469

PMid:22754938

40. Okamura T, Suzuki S, Ogawa T, Kobayashi J, Kusuoka O, Hatayama $\mathrm{K}$, et al. Background data for general toxicology parameters in RccHan: WIST rats at 8, 10, 19 and 32 weeks of age. J Toxicol Pathol. 2011;24(4):195-205. https://doi. org/10.1293/tox.24.195

PMid:22319231

41. Chanda S, Parekh J, Vaghasiya Y, Dave R, Baravalia Y, Nair R. Medicinal plants-from traditional use to toxicity assessment: A review. Int J Pharm. 2015;6(7):2652-70.

42. Diaz D, Hartley DP, Kemper R. Issue Investigation and Practices in Discovery Toxicology. USA: John Wiley \& Sons, Inc.; 2016.

43. Han ZZ, Xu HD, Kim KH, Ahn TH, Bae JS, Lee JY, et al. Reference data of the main physiological parameters in control spraguedawley rats from pre-clinical toxicity studies. Lab Anim Res. 2010;26(2):153-64. https://doi.org/10.5625/lar.2010.26.2.153

44. Bo L, Zhao G, Yin G, Sun H, Gao-Ling G, Yang X. Effect of breviscapine tablets on ventricular arrhythmias in hypertrophic myocardium of Rabbit Heart. J Xinxiang Med Coll. 2011;1:2154-6.

45. Organisation for Economic Co-operation and Development. OECD Guidelines for the Testing of Chemicals, Test No. 407: Repeated Dose 28-day Oral Toxicity Study in Rodents. Paris, France: Organisation for Economic Co-operation and Development. 2008. https://doi.org/10.1007/ springerreference_75881

46. Woo GH, Shibutani M, Ichiki T, Hamamura M, Lee KY, Inoue K, et al. A repeated 28-day oral dose toxicity study of nonylphenol in rats, based on the 'Enhanced OECD Test Guideline 407' for screening of endocrine-disrupting chemicals. Arch Toxicol. 2007;81(2):77-88. https://doi.org/10.1007/s00204-006-0129-6 PMid:16847671

47. Olorunnisola O, Bradley G, Afolayan A. Acute and sub-chronic toxicity studies of methanolic extract of Tulbaghia violacea Rhizomes in wistar rats. Afr J Biotechnol. 2012;11(83):14934-40. 
https://doi.org/10.5897/ajpp12.181

48. Balogun F, Ashafa A. Comparative study on the antioxidant activity of Dicoma anomala and Gazania krebsiana used in basotho traditional medicine. S Afr J Bot. 2015;98:170. https:// doi.org/10.1016/j.sajb.2015.03.014
49. Balogun SO, Damazo AS, de Oliveira Martins DT. Helicteres sacarolha A. St.-Hil. et al.: Gastroprotective and possible mechanism of actions in experimental animals. J Ethnopharmacol. 2015;166:176-84. https://doi.org/10.1016/j.jep.2015.03.021 PMid:25792014 